\title{
Phenotypic identification, nutrients content, bioactive compounds of two jengkol (Archidendron jiringa) varieties from Bengkulu, Indonesia and their potentials as ruminant feed
}

\author{
NUR HIDAYAH ${ }^{1, \boldsymbol{v}}$, RUKIAH LUBIS ${ }^{2}$, KOMANG G. WIRYAWAN ${ }^{3}$, SRI SUHARTI ${ }^{3}$ \\ ${ }^{1}$ Department of Animal Science, Faculty of Agriculture, Universitas Muhammadiyah Bengkulu. Jl. Bali, Bengkulu City 38113, Bengkulu, Indonesia. \\ Tel.: +62-736-7324582, `email: nurhidayah@umb.ac.id. \\ ${ }^{2}$ Department of Biology, Faculty of Teacher Training and Education, Universitas Muhammadiyah Bengkulu. Jl. Bali, Bengkulu City 38113, Bengkulu, \\ Indonesia \\ ${ }^{3}$ Department of Nutrition and Feed Technology, Faculty of Animal Science, Institut Pertanian Bogor. Jl Agatis Kampus IPB Darmaga, Bogor 16680,
} West Java, Indonesia

Manuscript received: 5 March 2019. Revision accepted: 21 May 2019.

\begin{abstract}
Hidayah N, Lubis R, Wiryawan KG, Suharti S. 2019. Phenotypic identification, nutrients content, bioactive compounds of two jengkol (Archidendron jiringa) varieties from Bengkulu, Indonesia and their potentials as ruminant feed. Biodiversitas 20: 1671-1680. Agricultural waste is abundant in tropical countries. Many farmers in these countries have been using this waste as the main sources for feeding livestock. Ones of them are jengkol (Archidendron jiringa) by-product like peels and leaves have not been utilized optimally. The aims of this study were to explore the peel and leaves of two varieties of jengkol, i.e., jengkol gajah and jengkol padi, from Bengkulu Province and to assess their potentials as ruminant feed. Variables observed were phenotypic identification, nutrients content, and bioactive compounds. Phenotypic identification was completed using non-experimental examination through survey and observation methods to identify the phenotypic characters of jengkol in four districts in Bengkulu. The peel of jengkol padi had a blackish purple color and was thicker than that of jengkol gajah. The leaves of jengkol gajah was longer $(10.2-15.5 \mathrm{~cm})$, but jengkol padi had wider leaves $(6-7.5 \mathrm{~cm})$. The proportion of weight of jengkol peel $(59.99 \%)$ is higher than seed $(40.01 \%)$. Jengkol peel had high fiber content (33.07-35.28\%) while the leaves were rich in protein and total digestible nutrient (TDN) (15.17-19.26\% and 63.87$65.82 \%$ ). In nutrient content comparison, the peel of jengkol padi was better (crude protein (CP:8.41\%, ether extract (EE):0.79\%, crude fiber (CF): $35.28 \%$ and total digestible nutrient (TDN): $52.81 \%$ but jengkol gajah had better nutrient in its leaves (CP:19.26\%, EE:2.50\%, CF:26.66\% and TDN:51.56\%). The saponin content (26.52\%), total phenol (2.99\%), and tannin (1.22\%) in the peel were higher than those in the leaves, while the leaves had higher flavonoids content (2.0\%) than the peels. Bioactive compounds in jengkol gajah were higher than those in jengkol padi. Based on this study, both jengkol gajah and jengkol padi are potential as ruminant feed in which the peel can be a source of fiber and saponins, while the leaves are potentially used as a source of protein, fiber and saponins.
\end{abstract}

Keywords: Archidendron jiringa, bioactive compounds, jengkol gajah, jengkol padi, phenotypic identification

\section{INTRODUCTION}

Jengkol (Archidendron jiringa (Jack) Nielsen) is a perennial woody plant species that have not been cultivated optimally. It is generally grown in forests and home gardens. The plant usually stands up to $25 \mathrm{~m}$ in height with a smooth, grey colored bark. Its beans which hang from the branches of the tree as coiled pods contain 3 to 9 beans per pod (Barceloux 2009). Jengkol has synonyms of Pithecellobium jiringa (Jack.) and Pithecellobium lobatum (Barceloux 2009) and is belong to Leguminosae family, sub-family of Mimosaceae. Some local names of jengkol are djenkol tree (Indonesia), krakos (Cambodia), jering (Malaysia), niang-yai (Thailand). According to Heyne (1987), in Indonesia jengkol has many local names, for example jering (Gayo, Batak), joring (Karo, Toba), jariang (Minangkabau), jaring (Lampung), jaring (Dayak), jengkol (Sunda), jingkol (Java), blandingan (Bali) and lubii (North Sulawesi).

Jengkol is native to tropical Southeast Asia. It is believed to be originated and widely distributed in
Indonesia, Malaysia and South Thailand where the seeds are popular as food. In 2017, Indonesia produced 66,065 tons of jengkol, which mostly grew in the western part of the archipelago, especially in Sumatra. Bengkulu is a province in Sumatra and is the fifth largest producer of jengkol in Sumatra and the ninth largest in Indonesia with total production of 2822 tons (BPS 2018). According to Indonesia Agricultural Directory report (2017), Bengkulu has several jengkol local varieties including jengkol gajah and jengkol padi. So far, the seeds have been used as culinary and medicine, while the by-products like peels and leaves have not been utilized optimally.

Yanti and Yayota (2017) reported that agricultural waste is abundant in tropical countries. Many farmers in these countries have been using this waste as the main sources to feeding livestock. Using agricultural wastes as feed can help farmers to reduce feed costs and minimize the environmental impacts of this waste. There are significant environmental, economic and social factors favoring the reutilization of agricultural wastes in farm animal nutrition (Kasapidou et al. 2015). Azevêdo et al. 
(2012) reported that ruminants play a valuable role in sustainable agricultural systems since they are capable of converting renewable natural resources, such as agricultural and agro-industrial by-products, into highquality feed for ruminant

There are limited studies about nutrients content and bioactive compounds from peels and leaves of jengkol, especially its local varieties such as jengkol gajah and jengkol padi commonly found in Bengkulu. Therefore there is a need to study the potentials of jengkol by-products of different varieties as alternative for ruminant feed. This study is aimed to explore the identification of phenotypes, nutrient contents, and bioactive compounds of jengkol peels and leaves of jengkol gajah and jengkol padi.

\section{MATERIALS AND METHODS}

\section{Phenotypic identification}

Phenotypic identification was carried out by descriptive non-experimental observations through identifying phenotypic characters using survey method with purposive sampling. Determination of location for sampling data collection based on preliminary survey. The survey locations were in four villages in four districts (kabupaten) in Bengkulu Province, indonesia, namely: Bukit Peninjau 1 Village (Seluma District), Paku Haji Village (Central Bengkulu District), Tanjung Dalam Village (North Bengkulu District), Embong Sido Village (Kepahiang District) (Figure 1). Samples were observed and measured directly, including leaves (shape, midrip, margin, apex, front side color, back side color, length, width, and thickness), pods and seeds (shape, amount, weight, length, width, and thickness) and peels (outer color, inner color, weight, length, width and thickness).

\section{Preparation of jengkol peels and leaves}

Jengkol peels and leaves were sun-dried for 5-6 hours until its weight was stable. After that, the materials were ground to form powder.

\section{Nutritional component analysis}

Nutritional component (ash, CP, EE, CF, and nitrogenfree extract (NFE) - of jengkol peels and leaves powder were determined according to Association of Official Analytical Chemists (AOAC) method (2005) and TDN was estimated according to Hartadi (1980). The neutral detergent fiber (NDF), acid detergent fiber (ADF), acid detergent lignin (ADL) were examined according to Goering and van Soest (1970). All test were carried out from 8 samples.

\section{Bioactive compounds analysis}

The bioactive compounds of jengkol peels and leaves measured in this study were saponin, total phenol, flavonoid, and tannin content.

Saponin analysis was according to Hiai dan Oura (1976) method and calibrated with standard solution of $0.01 \mathrm{~g}$ Diosgenin (Sigma-Aldrich D1634, Diosgenin Approx 95\%, Sigma Aldrich Chemie GmbH, Steinheim,
Germany). The samples of $0.2 \mathrm{ml}$ were added with $0.25 \mathrm{ml}$ of vanillin ethanol fresh and $2.5 \mathrm{ml}$ of $\mathrm{H}_{2} \mathrm{SO}_{4} 72 \%$, then stirred and heated on water bath (Watson Victor LTD, Bw6t, Watson Victor Limited, New Zealand, Australia) $60^{\circ} \mathrm{C}$ for 10 minutes. The samples were then cooled and beamed with UV-Vis spectrophotometer (UV-vis spectrophotometer, U-1800, 5930482, High Technology Corporation, Tokyo, Japan) with wavelength of $544 \mathrm{~nm}$.

Total phenol and tannin analysis was according to Makkar (2003) method and calibrated with standard solution of $0.1 \mathrm{mg} / \mathrm{ml}$ tannin acid (Merck). Total phenol and tannin were measured with Makkar (2003) method modified with the use of Folin-Ciocalteu using polyvinylpolypyrrolidone (PVPP) to separate phenol tannin from NTP. The samples were beamed with UV-Vis spectrophotometer (UV-vis spectrophotometer, U-1800, 5930482, High Technology Corporation, Tokyo, Japan) with wavelength of $724 \mathrm{~nm}$.

Flavonoid analysis was according to Meda et al. (2005) method with quercetin standard. The samples of $0.25 \mathrm{~g}$ were added with $1 \mathrm{~mL} \mathrm{AlCl}$ that had been dissolved with ethanol $80 \%$, and then were stirred for $20 \mathrm{~s}$ and beamed on wavelength $415 \mathrm{~nm}$.

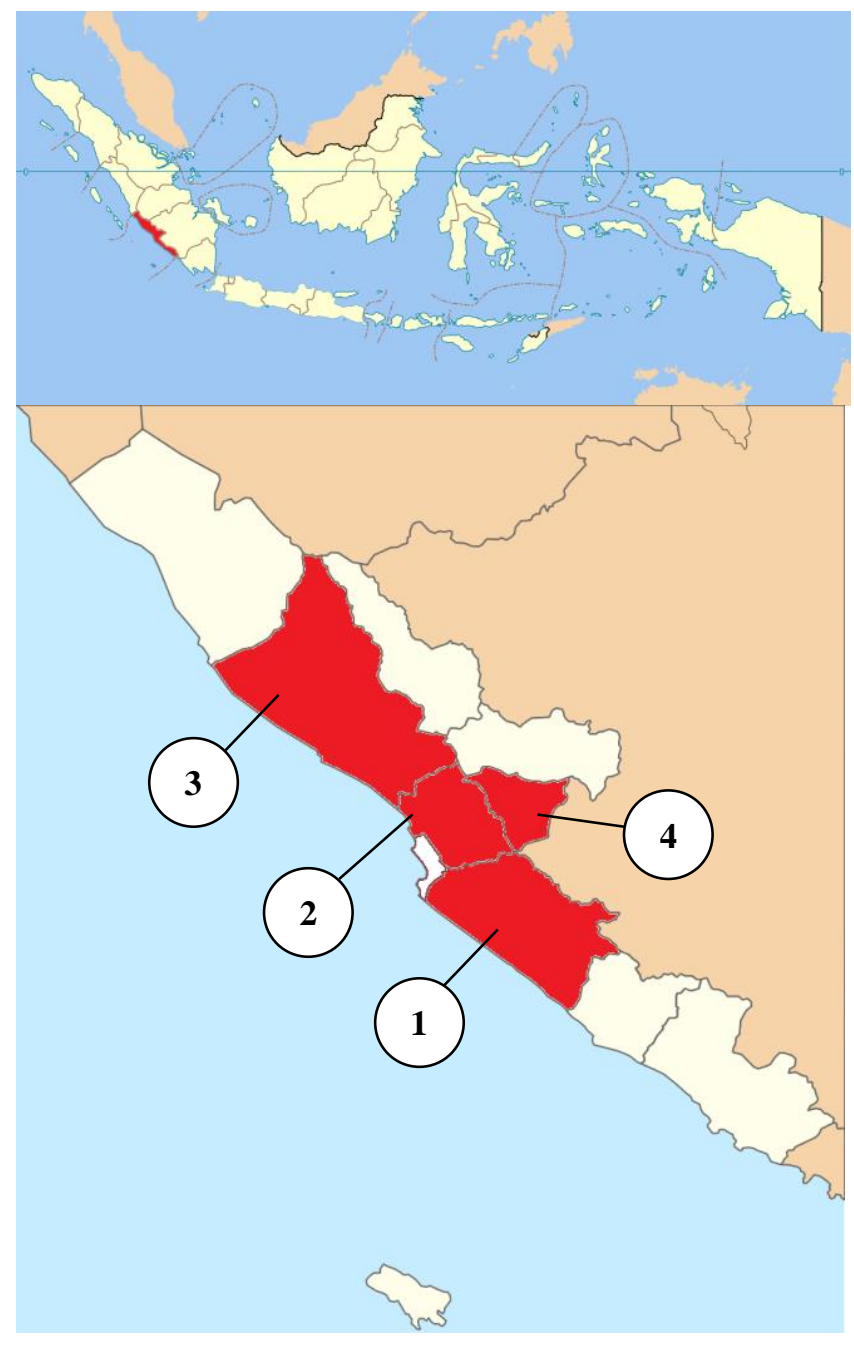

Figure 1. Location of the survey of Archidendron jiringa varieties in four districts of Bengkulu Province, indonesia. 1. Seluma, 2. Central Bengkulu, 3. North Bengkulu, 4. Kepahiang 


\section{Data analysis}

Data from phenotypic identification, nutrient analysis, and bioactive compound analysis were analyzed descriptively.

\section{RESULTS AND DISCUSSION}

\section{Phenotypic identification}

Jengkol found in four studied areas in Bengkulu Province can be grouped into two varieties, namely jengkol gajah and jengkol padi. In general, the results of observations from four locations in Bengkulu showed that jengkol gajah was the most commonly found variety. Jengkol gajah was found in Seluma, Bengkulu Tengah, and Bengkulu Utara Districts, while jengkol padi was only found in Kepahiang District (Table 1).

The phenotypic characterization showed that the leaves had ovate shape, pinnate midrip, entire margin, cupside apex, smooth surface and dark green color on the front side, lighter green and rough surface of its other side, around 10.2-15.5 cm of length, 5.3-7.5 cm of width, and $0.10-0.12 \mathrm{~mm}$ of thickness). The peels had blackish brown or blackish purple of outer color, brownish white of inner color, 4.5-6 cm of length, $4-5 \mathrm{~cm}$ of width, $13-23 \mathrm{~g}$ of weight, and $6-10 \mathrm{~mm}$ thick. The seeds had flat shape, around 8-22 $\mathrm{g}$ of weight, $3.5-4.5 \mathrm{~cm}$ length, $3-4 \mathrm{~cm}$ width, and $20-24 \mathrm{~mm}$ of thickness. The pods had curved and spiral shape.

Fauza et al. (2015) reported that jengkol plant has tap roots, brown fruits, straight round, and woody trunk, and has many branches. The leaves are compound with ovate shape, $10-20 \mathrm{~cm}$ of length, $5-15 \mathrm{~cm}$ of width, entire margin, cuspidate apex, rounded bases, pinnate midrib, dark green. It has compound flowers located at the end of the stem with purple color, and stamens and pistils have yellow color. The fruit is circular with blackish brown color, and the seeds are in two pieces with yellowish white color. Bunawan et al. (2013) reported that jengkol leaves are bipinnate up to $25 \mathrm{~cm}$ long and have grey glabrous bark. Fruit of this plant is falcate, twisted, deep purple $20-25 \mathrm{~cm}$ by $4-5 \mathrm{~cm}$ wide and easily broken by hand. It grows in large, dark purple pods which contain usually 3 to 9 beans. The characteristics are similar to qualitative traits recorded by Muslim and Abdul (2010) that the color of Pithecellobium jiringa (Jack.) is gray and pods are brown or black with red or purple inside. The pods consist of 3-9 beans with diameter $3.5 \mathrm{~cm}$ and thickness $2.0 \mathrm{~cm}$.

Table 1. Phenotypic characterization of two jengkol varieties in Bengkulu Province, Indonesia

\begin{tabular}{|c|c|c|c|c|}
\hline Location & $\begin{array}{c}\text { Bukit Peninjauan } 1 \\
\text { Village, } \\
\text { Seluma District } \\
\end{array}$ & $\begin{array}{c}\text { Paku Haji Village, } \\
\text { Center Bengkulu } \\
\text { Tengah District } \\
\end{array}$ & $\begin{array}{l}\text { Tanjung Dalam Village, } \\
\text { NorthBengkulu District }\end{array}$ & $\begin{array}{c}\text { Embong Sido Village, } \\
\text { Kepahiang District }\end{array}$ \\
\hline \multicolumn{5}{|l|}{ Leaves } \\
\hline Shapes & Ovate & Ovate & Ovate & Ovate \\
\hline Midrib & Pinnate & Pinnate & Pinnate & Pinnate \\
\hline Margin & Entire & Entire & Entire & Entire \\
\hline Apex & Cuspidate & Cuspidate & Cuspidate & Cuspidate \\
\hline Front side color & Dark green and smooth & Dark green and smooth & Dark green and smooth & Dark green and smooth \\
\hline Backside color & Green and rude & Green and rude & Green and rude & Green and rude \\
\hline Length & $10.5-14.5 \mathrm{~cm}$ & $10.2-15.5 \mathrm{~cm}$ & $13-14.5 \mathrm{~cm}$ & $10.5-14 \mathrm{~cm}$ \\
\hline Width & $5.5-7 \mathrm{~cm}$ & $5.3-6.5 \mathrm{~cm}$ & $5-5.5 \mathrm{~cm}$ & $6-7.5 \mathrm{~cm}$ \\
\hline Thickness & $0.10-0.12 \mathrm{~mm}$ & $0.10-0.12 \mathrm{~mm}$ & $0.12 \mathrm{~mm}$ & $0.11 \mathrm{~mm}$ \\
\hline \multicolumn{5}{|l|}{ Pod / Seed } \\
\hline Shapes & Very curvy and spiral & Very curvy and spiral & Very curvy and spiral & Curvy and spiral \\
\hline Number of seed per pod & 11 seeds & 10 seeds & 12 seeds & 6 seeds \\
\hline Weight per pod & $453 \mathrm{~g}$ & $341 \mathrm{~g}$ & $329 \mathrm{~g}$ & $178 \mathrm{~g}$ \\
\hline Weight (seed + peel $)$ & $37-48 \mathrm{~g}$ & $26-44 \mathrm{~g}$ & $28-33 \mathrm{~g}$ & $29-34 \mathrm{~g}$ \\
\hline Shapes & Circular and compact & Circular and compact & Circular and compact & Circular \\
\hline Weight & $19-22 \mathrm{~g}$ & $10-20 \mathrm{~g}$ & $15-18 \mathrm{~g}$ & $8-12 \mathrm{~g}$ \\
\hline Length & $4-4.5 \mathrm{~cm}$ & $4 \mathrm{~cm}$ & $4-4.5 \mathrm{~cm}$ & $3.5-4.5 \mathrm{~cm}$ \\
\hline Width & $4 \mathrm{~cm}$ & $3 \mathrm{~cm}$ & $3,5-4 \mathrm{~cm}$ & $3-4 \mathrm{~cm}$ \\
\hline Thickness & $22 \mathrm{~mm}$ & $22 \mathrm{~mm}$ & $24 \mathrm{~mm}$ & $20 \mathrm{~mm}$ \\
\hline \multicolumn{5}{|l|}{ Peel } \\
\hline Outer Color & Blackish brown & Blackish brown & Blackish brown & Blackish purple \\
\hline Inner Color & Brownish white & Brownish white & Brownish white & Brownish white \\
\hline Length & $4.5-6 \mathrm{~cm}$ & $4.5-5.5$ & $4.5-5 \mathrm{~cm}$ & $4.5-5.5 \mathrm{~cm}$ \\
\hline Width & $4.5-5 \mathrm{~cm}$ & $4.1-5$ & $4.2-4.5 \mathrm{~cm}$ & $4-4.5 \mathrm{~cm}$ \\
\hline Weight & $18-26 \mathrm{~g}$ & $16-23 g$ & $13-15 g$ & $20-23 \mathrm{~g}$ \\
\hline Thickness & $7 \mathrm{~mm}$ & $9 \mathrm{~mm}$ & $6 \mathrm{~mm}$ & $10 \mathrm{~mm}$ \\
\hline Varieties & Jengkol gajah & Jengkol gajah & Jengkol gajah & Jengkol padi \\
\hline \multicolumn{5}{|l|}{ Percentage } \\
\hline Peel weight & & $51.41 \%$ & & $68.57 \%$ \\
\hline Seed weight & & $48.59 \%$ & & $31.43 \%$ \\
\hline
\end{tabular}




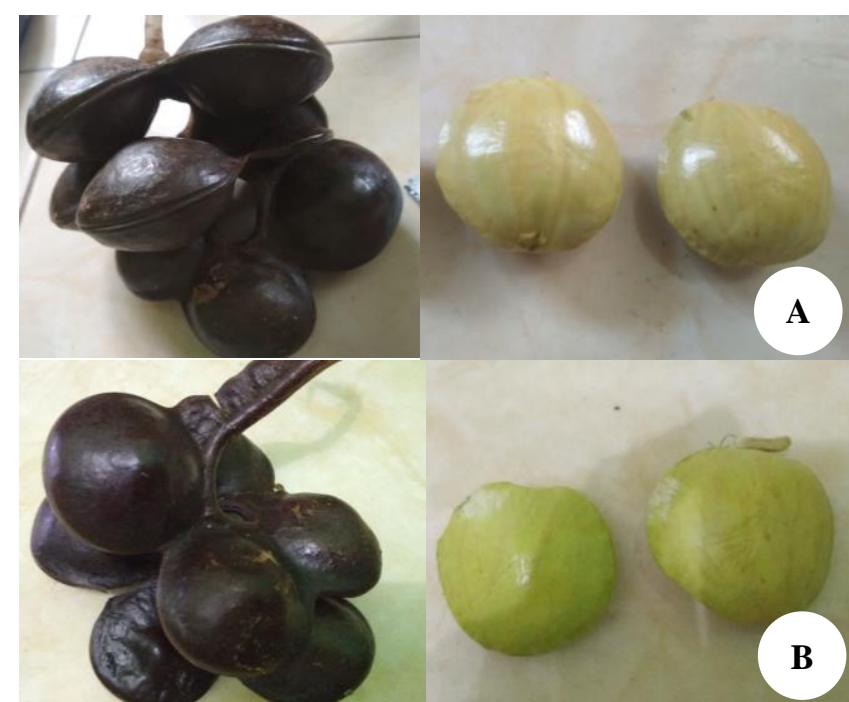

Figure 2. Phenotypic form of two jengkol varieties: A. Jengkol gajah, B. Jengkol padi.The black ones are pod and the green ones are the seed of jengkol

Our observation showed that jengkol gajah had thicker, heavier and more pods than jengkol padi. In one pod, jengkol gajah had more seeds than jengkol padi. Jengkol gajah had average 11 seeds in one pod, weighted around 19-22 $\mathrm{g}$ and $22 \mathrm{~mm}$ thickness of each seed. Jengkol padi had average 6 seeds per pod, weighted around 8-12 g, and $20 \mathrm{~mm}$ thickness of each seed. Jengkol gajah had a more circular and compact shape than jengkol padi. Jengkol gajah seed had thinner peel $(7 \mathrm{~mm})$ with blackish brown color than jengkol padi seed $(10 \mathrm{~mm}$ with blackish purple color almost looks like mangosteen peel). According to weight measurement, jengkol gajah total seed weight consists of $51.41 \%$ of peel and $48.59 \%$ of seed, while jengkol padi seed consists of $68.57 \%$ of peel and $31.43 \%$ of seed. These results indicated that across two varieties, the peel contributes higher proportion of weight than the seed. This is different from the result reported by Fauza et al. (2015) that found seed consists of $56 \%$ while peel consists of $44 \%$ of total seed weight.

Leaf is the main organ that supports plant growth and development by providing food processed through photosynthesis. The leaf size directly affects photosynthesis process and products. According to the observation, jengkol gajah has longer leaves, however, jengkol padi has wider leaves. The average both of length and width of leaves are $10-14 \mathrm{~cm}$ and $5-7.5 \mathrm{~cm}$, respectively. Based on the proportion of leaves size (2:1), generally, the shape of the leaves is elongated (oblongus) (Tjitrosoepomo 1993). Variation in agro-morphological character is affected by environmental (Mohammadi and Asadi-Gharneh 2018), developmental (Anandan et al. 2018), and genetical (Neugart et al. 2018) factors. The phenotypic differences between jengkol gajah and jengkol padi are shown in Figure 2 and jengkol plant structure is illustrated in Figure 3.

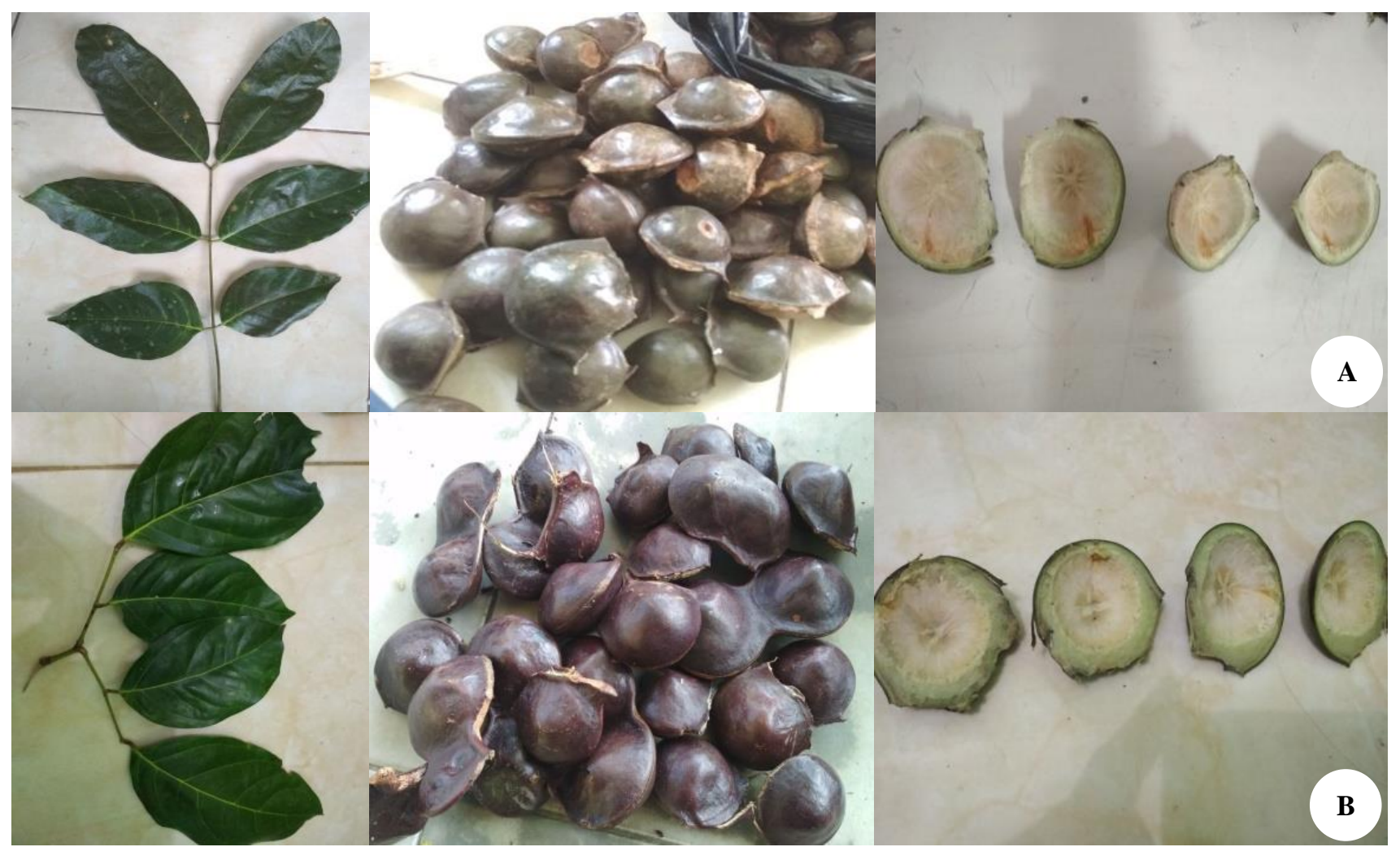

Figure 3. Characteristic of several organs (leaves, pod, and peel respectively): A. Jengkol gajah, B. Jengkol padi 
Table 2. Nutrient content of peel and leaves of jengkol gajah and jengkol padi varieties (100\% of DM/Dry Matter)

\begin{tabular}{lccccccc}
\hline \multicolumn{1}{c}{ Sample } & DM $(\%)$ & Ash $(\%)$ & CP $(\boldsymbol{\%})$ & EE $(\%)$ & CF $(\%)$ & NFE $(\%)$ & TDN $(\%)$ \\
\hline Jengkol gajah peel & 89.64 & 3.48 & 7.90 & 0.65 & 33.07 & 54.91 & 51.56 \\
Jengkol padi peel & 90.24 & 3.15 & 8.41 & 0.79 & 35.28 & 52.36 & 52.81 \\
Jengkol gajah leaves & 90.56 & 3.00 & 19.26 & 2.50 & 26.66 & 48.59 & 65.82 \\
Jengkol padi leaves & 90.61 & 2.70 & 15.17 & 2.25 & 25.14 & 54.74 & 63.87 \\
\hline
\end{tabular}

Note: 1. Estimation of TDN by Hartadi (1980) formula: TDN= $92.464-(3.338 \times \mathrm{CF})-(6.945 \times \mathrm{EE})-(0.762 \times \mathrm{Beta}-\mathrm{N})+(1.115 \times \mathrm{CP})+$ $\left(0.031 \times \mathrm{CF}^{2}\right)-\left(0.133 \times \mathrm{EE}^{2}\right)+(0.036 \times \mathrm{CF} \times$ Beta-N $)+(0.207 \times \mathrm{EE} \times$ Beta-N $)+(0.1 \times \mathrm{EE} \times \mathrm{CP})-\left(0.022 \times \mathrm{EE}^{2} \times \mathrm{CP}\right)$; 2. Proksimat Analysis PAU, IPB, Bogor (2018)

Table 3. NDF, ADF, cellulose, hemicellulose, and lignin compound of peel and leaves of jengkol gajah and jengkol padi varieties

\begin{tabular}{lccccc}
\hline \multicolumn{1}{c}{ Samples } & NDF $(\boldsymbol{\%})$ & ADF $(\boldsymbol{\%})$ & Hemicellulose $(\boldsymbol{\%})$ & Cellulose $(\boldsymbol{\%})$ & Lignin $(\boldsymbol{\%})$ \\
\hline Jengkol gajah peel & 55.33 & 40.84 & 14.49 & 26.99 & 15.48 \\
Jengkol padi peel & 58.74 & 43.78 & 14.96 & 28.23 & 16.42 \\
Jengkol gajah leaves & 44.16 & 36.03 & 8.13 & 18.15 & 17.75 \\
Jengkol padi leaves & 50.10 & 39.72 & 10.38 & 18.13 & 17.85 \\
\hline
\end{tabular}

Note: van Soest Analysis Livestock Research Center, Ciawi, Bogor (2018)

\section{Nutritional component analysis}

Nutrient components (ash, CP, EE, CF, NFE, TDN, $\mathrm{NDF}, \mathrm{ADF}$, cellulose, hemicellulose, and lignin) of jengkol peel and leaves are presented in Tables 2 and 3. Jengkol peel has higher CF (33.07-35.28\%) than leaves (25.14$26.66 \%$ ), while $\mathrm{CP}$ and TDN of leaves are higher than peel $(15.17-19.26 \%$ and $63.87-65.82 \%$ vs $7.90-8.41 \%$ and 51.56-52.81\%). These indicate that for ruminant feeding jengkol peel can be used as fiber sources while its leaves can be used as protein and fiber sources. Nutrient quality of agricultural waste can be used as fiber source for ruminant when CF $>18 \%$ of dry matter (DM) (Farda et al. 2015). Rinehart (2008) reported that fiber is necessary for proper rumen function, and is a source of energy as well. Jengkol peel has CF content of $33.07 \%$ and $35.28 \%$. These are higher than usual fiber sources for ruminant, such as native grasses (29.65\%), Pennisetum purpureum (31.29\%), Pennisetum purpupoides (32.23\%), Brachiaria decumbens (30.55\%), and Brachiaria humidicola (34.18\%) (Nasrullah et al. 2003). Ahmed et al. (2013) reported that mature plants usually contain higher CF than young plants. Seasonal variation also affects crude fiber contents. As plant become older, crude fiber contents tend to increase for all plants, but for some plants, the increase is higher than others. The stage of maturity of forage species can also be used to predict fiber content since fiber content in forage species increases with the stage of maturity $(\mathrm{Lu}$ et al. 2005). The crude fiber content from jengkol peel and leaves found in this study ranged from $25.14 \%$ to $35.28 \%$ which is in normal range according to the recommended value for ruminant. Therefore jengkol peel and leaves have adequate amount of crude fiber to support proper growth of ruminant livestock.

Jengkol leaves have $15.17 \%$ and $19.26 \%$ of CP content, almost similar to legumes leaves commonly used as protein source for ruminant such as Kaliandra (Calliandra calothyrsus) with 19.75\%, Calopo (Calopogonium muconoides) with $15.75 \%$, Centro (Centrosema pubescens) with $19.34 \%$, and Gamal (Gliricidia sepium) with $20.40 \%$ (Nasrullah et al. 2003; Foroughbakch et al. 2013). Lachman et al. (2005) reported that variety, growing area, and age of cultivation play important role in protein contents whereas cultivation method has less influence. Different developmental period, plant genotypes, and rowing conditions will result in significant differences in protein content of plant (Deans et al. 2016). Crude protein content of legume depends on developmental and growth stage (Aremu et al. 2017). Ahmed et al. (2013) reported that plants need more nitrogenous food for vegetative growth and therefore they efficiently store protein in early stages of growth in which is consumed later on during flowering and fruiting period followed by dormant phase while their nutritional contents are reduced. New shoot of vascular plants contains particularly high levels of protein, fat, and minerals, which makes them preferred for foraging after harsh winter conditions (Danell et al. 1994). Our results showed higher protein content from jengkol leaves, indicating that they were on early stage of growth. These findings suggest that the leaves from jengkol gajah and jengkol padi contained adequate $\mathrm{CP}$ to fulfill protein requirement of ruminants.

TDN is a standard system for expressing the energy value of feedstuff for ruminant. Our results showed that jengkol peel and leaves have high content of TDN (51.5665.82\%). TDN in jengkol leaves (63.87-65.82\%) is higher than in peel (51.56-52.81\%). This result is almost similar with Farda et al. (2015) who reported that agricultural wastes (leaves and stems of rice, sweet potato, and peanut) have TDN value of $49.05 \%, 49.64 \%$, and $60.61 \%$, respectively. Azevêdo et al. (2012) evaluated nutritional diversity of agricultural and agro-industrial by-products from regions throughout Brazil and showed that TDN of carrot leaves is $44.60 \%$, cassava leaves are $58.10 \%$, cassava hull is $52.30 \%$, cocoa eed hull is $49.90 \%$ and coffee hull is $42.50 \%$. Thus, the results of our study indicate that leaves and peel of jengkol could be used as 
partial source of energy for ruminant. Regarding variety, the peel of jengkol padi has higher nutrient content of $\mathrm{CP}$, EE, CF and TDN than jengkol gajah. While the leaves of jengkol gajah have higher nutrient content of $\mathrm{CP}, \mathrm{EE}, \mathrm{CF}$, and TDN than jengkol padi (Table 2).

Jengkol peel has higher NDF, ADF, hemicellulose, and cellulose than jengkol leaves, while the lignin content is almost the same between leaves and peel (Table 3). These results are in line with the fact that jengkol peel has higher $\mathrm{CF}$ than leaves. Lu et al. (2005) reported that chemically dietary fiber can be determined as crude fiber, neutral detergent fiber (NDF), acid detergent fiber (ADF), and acid detergent lignin. By mathematical differences, one can derive cellulose and hemicellulose. NDF content could be used to categorize feed quality. Singh and Oosting (1992) pointed out that roughage feeds containing NDF values of less than $45 \%$ could be classified as high quality, those with values ranging from $45 \%$ to $65 \%$ as medium and those with values higher than $65 \%$ as low quality. Based on the category, jengkol peel and leaves can be classified as medium quality (44.16-58.74\%). Based on ADF values, jengkol leaves (36.03-39.72\%) is classified as high-quality forage feed, but the peel $(40.84-43.78 \%)$ is classified as low quality. According to Kellems and Church (2002), roughage with less than $40 \%$ ADF are categorized as high quality and those with greater than $40 \%$ as poor quality.

The content of NDF, hemicellulose, and cellulose of jengkol peel (55.33-58.74\%, 14.49-14.96\%, 26.99-28.23\%) are still lower compared to various grasses often used as livestock feeds, but the ADF and lignin are relatively higher (40.84-43.78\%, 15.48-16.42\%) (Table 3). Nasrullah et al. (2003) reported that NDF, ADF, hemicellulose, cellulose and lignin from some grasses: Native grasses: $68.09 \%, 34.55 \%, 33.53 \%, 23.07 \%, 6.08 \%$; Pennisetum purpureum: 66.96\%, 35.55\%, 31.21\%, 25.93\%, 5.03\%; Pennisetum purpupoides: 69.37\%, 39.10\%, 30.27\%, 26.37\%, 6.65\%; Brachiaria decumbens: 68.16\%, 34.62\%, $33.55 \%, 26.33 \%, 4.81 \%$ and Brachiaria humidicola: $73.51 \%, 40.71 \%, 32.80 \%, 30.65 \%, 6.94 \%$. Similar report is also made by Azevêdo et al. (2012) who found that coffee hull has NDF of $57.10 \%$ and ADF of $45.80 \%$; soybean hull has NDF of $67.50 \%$ and ADF of $45.40 \%$.

The higher is ADF value, the lower is livestock digestibility for each feed (Crampton and Haris 1969). The low digestibility is because $\mathrm{ADF}$ contains $15 \%$ pentose called pentose micellar which is difficult to digest compared to other types of carbohydrates. Pentose is a mixture of araban, xylan and other substances that can be found in plants when under hydrolysis both substances produce arabinose and xylose which can be found in hemicellulose. Waghorn et al. (2003) reported that hemicellulose and cellulose are rapidly and extensively degraded by rumen microflora when lignin is absence. Lignin has complex components which are difficult to degrade thus to break it down requires cellulose enzymes, hemicellulose and ligninase enzyme (Schiere and Ibrahim 1989), because of lignin influence formation of cross-linkages between cellulose and hemicellulose. Lignification in forages causes substantial reductions in the rate and extent of cell wall degradation and nutritive value of that forage for ruminant (Waghorn et al. 2003). In this study, lignin content of jengkol seed varied from 15.48 to $16.42 \%$, which is almost the same as lignin content of rice straw with $16.62 \%$ (Dewi 2002), coffee hull with $17.5 \%$ and cocoa seed hull (Azevêdo et al. 2012). The high lignin content may be caused by maturity of forage, and genetical and environmental factors. Rinehart (2008) reported that the younger is a plant, the more soluble carbohydrates it contains, and the less cell wall components it contains as well. Younger plants have low lignin content, therefore they are generally more digestible than mature plants. Considerable genetic variation for cell-wall digestibility in grasses has been established both between and within species (Grabber at al. 2004). Tronchet et al. (2010) reported that lignin biosynthesis can also be induced upon various biotic and abiotic stress conditions, such as wounding, pathogen infection, metabolic stress, and perturbations in cell wall structure. Chopping is one way of reducing the impact of lignification on cell wall digestion (Waghorn et al. 2003).

\section{Bioactive compounds}

Jengkol peel and leaves contain bioactive compounds such as saponin, total phenol, flavonoid, tannin, steroid, dan triterpenoid (Tables 4 and 5). Quantitative analysis showed that jengkol gajah peel contains saponin of $35.13 \%$ while jengkol gajah leaves, jengkol padi peel, jengkol padi leaves contain $19.31 \%$, is $17.91 \%$, and is $8.26 \%$, respectively. These results suggest that saponin content in jengkol gajah is higher than in jengkol padi, while saponin content in peel is higher than leaves. The saponin content in jengkol gajah peel is two times higher than in jengkol padi peel or jengkol gajah leaves. The leaves of jengkol padi had the lowest saponin content which is 8 times lower than jengkol gajah peel. The different percentage of saponin content is affected by plant species, genetic origin, the part of the plant being examined, the environmental and agronomic factors associated with growth of the plant, and post-harvest treatments such as storage and processing (Fenwick et al. 1991).

These results indicate that the peel and leaves of both jengkol gajah and padi can be used as potential sources of saponin. Kragiel et al. (2017) reported that many sources of saponin including hore-chestnut $(3 \%)$, leaves of sugar beet $(5.8 \%)$, chinese gingseng (2-3\%), quillaja bark (9-10\%), and yucca $(10 \%)$. Wina and Sutanto (2016) reported that saponin sources in Indonesia include hibiscus leaves (Hibiscus rosasinensis), waru leaves (Hibiscus tiliaceus) with saponin content of $8.93 \%$ of DM (Istiqomah et al. 2011), leaves and bark of Enterolobium cyclocarpum, Morinda citrifolia, Sesbania sesban, Albizia saponaria, and mangosteen peel with saponin $15.7 \%$ of DM (Poungchompu et al. 2009), eggplant fruit or dioscorea tuber. Majinda (2012) reported that the most well-known sources of saponin are some herbs with names that indicate foaming properties, such as soapwort (Saponaria officinalis), soapberry (Sapindus saponaria), soapbark (Quillaja saponaria), soaproot (Chlorogalum pomeridianum), soapnut (Sapindus mukurossi), and soapwood (Clethra occidentalis). Commercial saponins are extracted from Quillaja saponaria and Yucca schidigera. 
Table 4. Phytochemical compounds in peel and leaves of jengkol gajah and jengkol padi varieties

\begin{tabular}{lccccc}
\hline \multicolumn{1}{c}{ Phytochemical } & \multicolumn{2}{c}{ Peel } & \multicolumn{2}{c}{ Leaves } \\
\cline { 2 - 5 } & Jengkol gajah & Jengkol padi & Jengkol gajah & Jengkol padi \\
\hline Saponin & ++++ & ++++ & +++ & ++ & ++ \\
Phenol Hidroquinon & +++ & +++ & +++ & + & ++ \\
Flavonoid & +++ & +++ & + & ++ \\
Tannin & + & + & ++ & + \\
Steroid & + & ++ & + & + \\
Triterpenoid & + & - & - & + \\
Alkaloid & - & + & + & + \\
\hline
\end{tabular}

Note: (-) not detected, (+) low positive, $(++)$ positive, $(+++)$ strong positive, $(++++)$ very strong positive

Table 5. Saponin, flavonoid, total phenol and tanin compounds in the peel and leaves of jengkol gajah and jengkol padi varieties $(100 \% \mathrm{DM})$

\begin{tabular}{lcccc}
\hline \multicolumn{1}{c}{ Samples (powder form) } & Saponin $(\boldsymbol{\%})$ & Total phenol $(\boldsymbol{\%})$ & Flavonoid $(\boldsymbol{\%})$ & Tannin $(\boldsymbol{\%})$ \\
\hline Jengkol gajah peel & 35.13 & 3.12 & 1.85 & 1.43 \\
Jengkol padi peel & 17.91 & 2.85 & 0.12 & 1.01 \\
Jengkol gajah leaves & 19.31 & 2.72 & 1.90 & 1.26 \\
Jengkol padi leaves & 8.26 & 1.32 & 2.10 & 0.60 \\
\hline
\end{tabular}

Note: Biactive Compound Analysis Livestock Research Center, Ciawi, Bogor (2018)

Saponins are secondary compounds found in many plants (roots, peel, leaves, seeds, and fruit) that have functioned as a defense system. The presence of saponin can be characterized by the presence of bitter taste, the formation of a stable foam in a liquid solution. It has ability to form molecules with cholesterol (saponin-cholesterol complexes form) (Francis et al. 2002). Saponins are used in the treatment of hypercalciuria and have also been found to significantly affect growth, feed intake and reproduction in animals. Saponins have also been observed to kill protozoans and molluscs and act as antifungal and antiviral agent (Sciences and Sarani 2012). Saponin containing plants as a possible means of suppressing or eliminating protozoa in the rumen. Decreased numbers of ruminal ciliate protozoa may enhance the flow of microbial protein from the rumen, to increase the efficiency of feed utilization and decrease methanogenesis. Saponins are also known to influence both the composition and number of ruminal bacterial species through specific inhibition or selective enhancement of the growth of individual species. Saponins have been shown to possess strong defaunation properties both in vitro and in vivo which could reduce methane emissions (Wina 2005; Suharti 2011; Wanapat et al. 2013).

The analysis showed that the content of total phenol in jengkol gajah peel is $3.12 \%$, jengkol padi peel is $2.72 \%$, jengkol gajah leaves is $2.85 \%$ and jengkol padi leaves is $1.32 \%$. These results indicate that the total phenol content in jengkol gajah is higher than in jengkol padi and content in peel is higher than leaves. The different proportion of phenol content is caused by the anatomical part of the plants, phenology (growth and life cycle), the stage of maturity of the plant and chemo-type, agronomic factors (e.g. conditions of cultivation and harvesting, irrigation, fertilization and methods of harvest) (Preface 2012). Kliebenstein (2012) reported that the level of phenolics in plants is affected by many factors including genetic and physiological factors as well as environmental factors (high and low temperature, drought, alkalinity, salinity, UV stress, bacteria, fungi, insects, etc). According to Alfaro et al. (2013), growing season and genotype play significant role in polyphenol content, antioxidant activity, and dry matter of murtilla fruits from three genotypes. Barreira et al. (2008) reported that chestnut was a natural antioxidant source with phenol content. Flower of chestnut contains phenol of $1.92 \%$, leaf with $2.90 \%$, outer peel with $3.69 \%$, and inner peel with $5.70 \%$. Peel bark of chestnut is revealed as the best antioxidant properties, presenting much lower EC50 values, particularly for lipid peroxidation inhibition in the TBARS assay.

Phenol is a bioactive compound serving as antioxidant, antiviral, antibacterial, anti-mutagenic and anticarcinogenic. As antioxidants, phenol depends on several factors such as alternating hydroxyl groups in the aromatic ring and their ability to give hydrogen or electron donors and their ability to eradicate free radicals (Makgope 2006). Leiber et al. (2012) reported that in vivo studies have to confirm these potentially beneficial effects of buckwheat if used as forage for ruminants and clarify the role of further phenolic compounds present in buckwheat. In a recent study (Vasta et al. 2010) investigated the effects of phenol in Cistus ladanifer and in grape seed extract in meat volatile compounds of fat-enriched diets of lambs. The result reported that cistus had a protective effect against oxidation and reduced lipid autoxidation on lamb. The direct addiction of purified phenol or polyphenol-rich plant extracts was shown to delay oxidative deterioration in meat and in muscle model systems (Maqsood and Benjakul 
2010). Feeding lambs with concentrate-based diets with the inclusion of a polyphenol-rich extract from quebracho (Schinopsis lorentzii) can delay myoglobin oxidation and extend the color stability of meat stored both in highoxygen modified atmosphere and in aerobic conditions (Luciano et al. 2011). Our analysis showed that the content of flavonoids in jengkol padi leaves is $2.10 \%$, jengkol gajah leaves is $1.90 \%$, jengkol gajah peel is $1.85 \%$, and jengkol padi peel is $0.12 \%$. These results indicate that flavonoid content in jengkol gajah is higher than in jengkol padi, while flavonoids content in peel is higher than in leaves. Different flavonoid contents may be influenced by different genetic, agronomic, and environmental factors. According to Lee et al. (2003), there was positive correlation between the duration of exposure to sunshine and flavonoid content in leaves of Angelica keiskei. Assimilation rate and stomatal conductance were greater in leaves of Olea europaea plants grown under full-sun than under partial shading, while concentration of flavonoid (quercetin and luteolin glycosides, but not that of apigenin glycosides) increased in leaves fully exposed to sunlight irradiance in comparison with those under partial shading (Remorini et al. 2009). Ultraviolet light influences dry weight of flowers, leaves, and roots, leaf area, photosynthetic parameters, and transpiration rate depending on wavelength and intensity of radiation, and temperature affects plant total dry mass, leaf area, and root respiration so influence content of bioactive compound (Cooley et al. 2000).

Flavonoids as benzo-pyrone derivatives of phenolic compound are included of a large family of thousands of hydroxylated polyphenolic compounds. Flavonoids are important class of phytochemicals products found in most of herbs, fruits, vegetables and certain beverages (Kumar and Panday 2013). Flavonoids are divided into three groups based on their physiological functions: anthocyanin (flavonoids that act as color pigment), flavonols and flavones (protection against excessive UV radiation and biological signal), and isoflavones (binary flavonoids that play many roles as defense compound). According to Kalantar (2018), addition of flavonoids to ruminant diets could suppress methane production without influencing rumen microbial fermentation, fatty acid production, and performance of beef or dairy cattle. Flavonoids are able to improve volatile fatty acids production together with reduction in both rumen ammonia concentration and methane production which are considered as desirable changes in rumen environment. Also, the positive effect of flavonoids on rumen microbial fermentation and nutritional stress such as bloat or acidosis. Flavonoids can also promote the growth and development of animals as well as improve the quality of animal products. Olagaray and Bradford (2019) reported that flavonoids can increase ruminant productivity with beneficial effects exhibited under a variety of stressful conditions. Supplementing different flavonoids to dairy cows during the transition period showed their potential to reduce postpartum inflammation, endoplasmic reticular stress, and hepatic lipid accumulation, increased milk yield, and reduced milk somatic cell.
The results showed that tannin content in jengkol gajah peel is $1.43 \%$, jengkol gajah leaves is $1.26 \%$, jengkol padi peel is $1.01 \%$, and jengkol padi leaves is $0.60 \%$. These results indicate that tannin content in jengkol gajah is higher than in jengkol padi while tannin content in peel is higher than in leaves. War et al. (2012) reported that the level of tannins found in most plant tissues, such as fruit and leaves, is normally in the range of $2-5 \%$ of the fresh weight, but in pathological conditions, a rapid accumulation of tannins may occur. The induction of tannin in plant tissues is also stimulated by abiotic stresses such as UV-light (Mellway and Constabel 2009), hydric stress, temperature, ozone, and nutrient availability (Treutter 2006).

Tannins are phenolic secondary compounds of plants found in approximately $80 \%$ of woody perennial dicotyledons and $15 \%$ of annual and herbaceous perennial dicotyledon species, and are present in feeds, foods, and drinks (Mueller-Harvey 1999). They are presence in almost every part of a plant - seeds, fruit, leaves, wood, bark, and root, where their principal function is to provide protection against microbial pathogens, insect, pests, and herbivores (Dixon et al. 2005). The most commonly occurring tannins are typically divided into two major classes based on chemical structure: hydrolyzable (HT) or condensed tannins (CT). Hydrolyzable tannins are esters of gallic or ellagic acid linked to a polyol core, typically glucose. Condensed tannins or proanthocyanidins consist of flavan3-ol sub-units linked together to form oligomers and polymers (Naumann et al. 2017). Mueller-Harvey (2006) reported that tannin has several positive effects in ruminant, such as increase protein efficiency, accelerate livestock growth, increase milk production, increase livestock fertility, prevent bloat, and inhibit nematode infection. The use of low-to-moderate CT in diets allows for increases in the efficiency of protein digestion and may improve animal health and production under grazing, depending upon the concentration and chemical structure of these compounds (Ramírez-Restrepo and Barry 2005). Tannin can be used to reduce methane emissions, improve livestock feed efficiency and safe for livestock and environment (Jayanegara et al. 2015; Hidayah 2016)

Jengkol by-products like peels and leaves of two varieties (gajah and padi) are very potential to be used as ruminant feed. They are available in high quantity. The proportion of weight of jengkol peel $(59.99 \%)$ is higher than seed $(40.01 \%)$, so if Bengkulu Province produced 2822 tons of jengkol, there would be 1580 tons of peels available. In term of nutritional value, jengkol peels and leaves contain $25.14 \%$ to $35.28 \%$ of crude fiber. This value is within the range of the recommended value for ruminant, making Jengkol peels and leaves potential to be used as a crude fiber source. Jengkol leaves also make a good source of protein, with $15.17 \%$ and $19.26 \%$ of crude protein. Jengkol peels and leaves have high content of total digestible nutrient (51.56-65.82\%). This makes them a good partial source of energy for ruminant. Lastly, Jengkol peels and leaves are also a potential saponin source (8.26$35.13 \%$ ) which can be used as an alternative to natural feed additive to increase animal productivity. 


\section{ACKNOWLEDGMENTS}

The authors gratefully acknowledge financial support from the Ministry of Research, Technology and Higher Education of the Republic of Indonesia under the PKPT (Penelitian Kerjasama Perguruan Tinggi) Grant No. 2128/SP2H/LT/K2/KM/2018.

\section{REFERENCES}

Ahmed K, Shaheen M, Mirzaei F, Khan ZI, Gondal S, Fardous A, Hussain A, Arshad F, Mehmood T. 2013. Proximate analysis: relative feed values of various forage plants for ruminants investigated in a semiarid region of Punjab, Pakistan. Agric Sci 4(6): 302-308.

Alfaro S, Mutis A, Palma R, Quiroz A, Seguel I, Scheuermann E. 2013. Influence of genotype and harvest year on polyphenol content and antioxidant activity in murtilla (Ugni molinae Turcz) fruit. J Soil Sci Plant Nutr 13: 67-78

Anandan S, Rudolph A, Speck T, Speck O. 2018. Comparative morphological and anatomical study of self-repair in succulent cylindrical plant organs. Flora 241: 1-7

Aremu MO, Audu SS. Gav BL. 2017. Comparative review of crude protein and amino acid composition of some leguminous seeds grown in Nigeria. Intern J of Sci 6: 88-97.

AOAC. 2005. Official Methods of Analysis of AOAC International. 18th ed. Assoc. Off. Anal. Chem., Arlington

Azevêdo JAG, Filho V, Pina DS, Detmann E, Pireira LGR, Valadares RFD, Fernandes HJ, Silva LFC, Benedeti PB. 2012. Nutritional diversity of agricultural and agro-industrial by-products for ruminant feeding. Arq Bras Med Vet Zootec 64: 1246-1255.

Badan Pusat Statisitik. 2018. Produksi tanaman sayuran jengkol (ton) https://www.bps.go.id/site/resultTab._[ndonesian]

Balai Resmi PVT. 2017. Pendaftaran Varietas Lokal Jengkol. pvtpp.setjen.pertanian.go.id/cms/wp.../236.-Jengkol-Gajah-TP.pdf. [1 October 2018] [Indonesian]

Barceloux DG. 2009. Djenkol Bean [Archidendron jiringa (Jack) I. C. Nielsen]. In Medical Toxicology of Natural Substances: Foods, Fungi, Medicinal Herbs, Toxic Plants, and Venomous Animals. John Wiley \& Sons, Hoboken, New Jersey

Barreira JCM, Ferreira ICFR, Oliveira MBPP, Pereira JA. 2008 Antioxidant activities of the extracts from chestnut flower, leaf, skin and fruit. Food Chem 107: 1106-13.

Bunawan H, Dusik L, Bunawan SN, Amin NM. 2013. Botany, traditional uses, phytochemistry and pharmacology of Archidendron jiringa: a review. Glob J of Pharm 7 (4): 474-478.

Cooley NM, Holmes MG, Attridge TH. 2000. Growth and stomatal responses of temperate meadow species to enhanced levels of UV-A and UV-B + A radiation in the natural environment. J Photochem Photobiol Biol 57: 179-185.

Crampton EW, Haris LE. 1969. Applied Animal Nutrition E, d. 1 st. The Engsminger Publishing Company, California USA.

Danell K, Utsi PM, Palo RT, Erricksson O. 1994. Food plant selection by reindeer during winter in relation to plant quality. Ecography 17: 153158.

Deans CA, Behmer ST, Fiene J, Sword GA. 2016. Spatio-temporal, genotypic, and environmental effects on plant soluble protein and digestible carbohydrate content: implications for insect herbivores with cotton as an exemplar. J Chem Ecol 42: 1151-1163.

Dewi. 2002. Hidrolisis limbah hasil pertanian secara enzimatik. J Akta Agrosia 5: 67- 71 [Indonesian]

Dixon RA, Xie D, Sharma SB. Proanthocyanidins - a final frontier in flavonoid research?. New Phytol Trust. https://doi.org/10.1111/j.1469-8137.2004.01217.x.

Fauza H, Ferita I, Putri NE, Nelly N, Rusman B. 2015. Studi awal penampilan fenotipik plasma nutfah jengkol (Pithecollobium jiringa) di Padang, Sumatera Barat. Prosiding Seminar Nasional Masyarakat Biodiversitas Indonesia, Depok, 20 December 2014 [Indonesian]

Farda FT, Laconi EB, Mulatsih S. 2015. Feed potential of agriculture waste for beef cattle development in Kuningan Regency, West Java. J Indonesian Trop Anim Agric 40: 167-175.
Fenwick GR, Price KR, Tsukamoto C, Okubo K. 1991. Saponins. In: D'Mello JPF, Duffus CM, Duffus JH (eds). Toxic Substances in Crop Plants. The Royal Society of Chemistry, Cambridge.

Foroughbakch R, Hernández-Piñero JL, Carrillo-Parra A, Rocha-Estrada A. 2013. Composition and animal preference for plants used for goat feeding in semiarid Northeastern Mexico. J Anim Plant Sci 23 (4): 1034-1040.

Francis G, Kerem Z, Makkar HPS, Becker K. 2002. The biological action of saponins in animal system: A review. Br J Nurt 88: 587-605.

Goering HK, Van Soest PJ. 1970. Forage Fiber Analysis. Agriculture Handbook 379. USDA, Washington DC.

Grabber JH, Ralph J, Lapierre C, Barrière Y. 2004. Genetic and molecular basis of grass cell-wall degradability. I. Lignin-cell wall matrix interactions. C R Biol 327: 455-465.

Hartadi H, Reksohadiprodjo S, Lebdosukojo S, Tillman AD. 1980. Tabel Komposisi Pakan untuk Indonesia. Gajah Mada University Press, Yogyakarta [Indonesian]

Heyne K. 1987. Tumbuh-Tumbuhan Berguna Indonesia Jilid III (terjemahan Nur Udin). Badan Litbang Kehutanan, Jakarta [Indonesian]

Hiai S, Oura HNT. 1976. Color reaction of some sapogenins and saponins with vanillin and sulfuric acid. Plant Med 29: 116-122.

Hidayah N. 2016. Pemanfaatan senyawa metabolit sekunder tanaman (tanin dan saponin) dalam mengurangi emisi metan ternak ruminansia. JSPI 11: 89-98 [Indonesian]

Istiqomah L, Herdian H, Febrisantosa A, Putra D. 2011. Waru leaf (Hibiscus tiliaceus) as saponin source on in vitro ruminal fermentation characteristic. J Indones Trop Anim Agric 36: 43-49.

Jayanegara A, Goel G, Makkar HPS, Becker K. 2015. Divergence between purified hydrolysable and condensed tannin effects on methane emission, rumen fermentation and microbial population in vitro. Anim Feed Sci Technol 209: 60-68.

Kalantar M. 2018. The Importance of Flavonoids in Ruminant Nutrition. Arch Anim Husb Dairy Sci 1: 1-4

Kasapidou E, Sossidou E, Mitlianga P. 2015. Fruit and vegetable coproducts as functional feed ingredients in farm animal nutrition for improved product quality. Agriculture 5: 1020-1034.

Kellems RO, Church DC. 2002. Livestock Feeds and Feeding (4 ${ }^{\text {th }}$ edition). Prentice-Hall Inc., New Jersey.

Kliebenstein DJ. 2012. Plant defense compounds: systems approaches to metabolic analysis. Annu Rev Phytopathol 50: 155-73.

Kragiel D, Antolak H, Witonska IA, Proestos C. 2017. Saponin-Based, Biological-Active Surfactants from Plants. Intech, United Kingdom.

Kumar S, Pandey AK. 2013. Chemistry and biological activities of flavonoids. An overview Sci World J 1-16.

Lachman J, Hamaouz K, Dvořák P, Orsák M. 2005. The effect of selected factors on the content of protein and nitrates in potato tubers. Plant Soil Environ 51: 431-438.

Lee JH, Lee JY, Kim KN, Kim HS. 2003. Quantitative analysis of two major flavonoid aglycones in acid hydrolyzed samples of Angelica keiskei by HPLC. Food Sci Biotechnol 12: 415-418.

Leiber F, Kunz C, Kreuzer M. 2012. Influence of different morphological parts of buckwheat (Fagopyrum esculentum) and its major secondary metabolite rutin on rumen fermentation in vitro. Czech J Anim Sci 57: 10-18.

Lu CD, Kawas JR, Mahgoub OG. 2005. Fibre digestion and utilization in goats. Small Ruminant Res 60: 45-52.

Luciano G, Vasta V, Monahan FJ, Lòpez-Andrés P, Biondi L, Lanza M, Priolo A. 2011. Antioxidant status, colour stability and myoglobin resistance to oxidation of Longissimus dorsi muscle from lambs fed a tannin-containing diet. Food Chem 124: 1036-1042.

Majinda RRT. 2012. Extraction and isolation of saponins. In Satyajit DS, Nahar L (eds). Natural Products Isolation, Methods in Molecular Biology. 864: 415-426.

Makgope LB. 2006. Cowpea seed coats and their extracts: phenolic composition and use as antioxidants in sunflower oil. [MSc Dissertation]. University of Pretoria, Pretoria. [South Africa]

Makkar HPS. 2003. Quantification of Tannins in Tree and Shrub Foliage. A Laboratory Manual. Kluwer Academic Publishers, Dordrecht, Netherlands

Maqsood S, Benjakul S. 2010. Preventive effect of tannic acid in combination with modified atmospheric packaging on the quality losses of the refrigerated ground beef. Food Control 21: 1282-1290.

Meda A, Lamien CE, Romito M, Millogo J, Nacoulma OG. 2005. Determination of the total phenolic, flavonoid and proline contents in 
Burkina Fasan honey, as well as their radical scavenging activity. Food Chem 91: 571-577.

Mellway RD, Constabel CP. 2009. Metabolic engineering and potential functions of proanthocyanidins in poplar. Plant Signaling Behav 4: 790-792.

Mueller-Harvey. 1999. Tannins their nature and biological significance, In: Caygill JC, Mueller-Harvey I. (eds). Secondary Plant Products: Antinutritional and Beneficial Actions in Animal Feeding. Nottingham University Press, Nottingham, United Kingdom.

Mueller-Harvey I. 2006. Unravelling the conundrum of tannins in animal nutrition and health. J Sci Food Agric 86: 2010-2037.

Mohammadi M, Asadi-Gharneh HA. 2018. How the morphological properties of Mentha longifolia.(L.) Huds. may be affected by geographical differences. J Photochem Photobiol B Biol 178: 237242.

Muslim N, Abdul MA. 2010. Pithecellobium jiringa: A traditional medicinal herb. Webmed Central Complementary Medicine 1: 1-4

Nasrullah M. Niimi, Akashi R, Kawamura O. 2003. Nutritive evaluation of forage plants grown in South Sulawesi, Indonesia. Asian-Aust. J Anim Sci 16: 693-701.

Naumann HD, Tedeschi LO, Zeller WE, Huntley NF. 2017. Invited Review: The role of condensed tannins in ruminant animal production: advances, limitations and future directions. Rev Bras Zootec 46 (12): 929-949.

Neugart S, Baldermann S, Hanschen FS, Klopsch R, Wiesner-Reinhold M, Schreiner M. 2018. The intrinsic quality of brassicaceous vegetables: How secondary plant metabolites are affected by genetic, environmental, and agronomic factors. Sci Hortic 233: 460-478.

Olagaray KE, Bradford BJ. 2019. Plant flavonoids to improve productivity of ruminants - A review. J Anim Feed Sci 1: 1-53.

Poungchompu O, Wanapat M, Wachirapakorn C, Wanapat S, Cherthong A. 2009. Manipulation of ruminal fermentation and methane production by dietary saponins and tannins from mangosteen peel and soapberry fruit. Arch Anim Nutr 63: 389-400.

Preface. 2012. Plant bioactive compounds in ruminant agriculture Impacts and opportunities. Anim Feed Sci 176: 1-4.

Ramírez-Restrepo CA, Barry TN. 2005. Alternative temperate forages containing secondary compounds for improving sustainable productivity in grazing ruminants. Anim Feed Sci Technol 120: 179201.

Remorini D, Melgar JC, Guidi L, Degl'Innocenti E, Castelli S, Traversi ML, Massai R, Tattini M.2009. Interaction effects of root-zone salinity and solar irradiance on the physiology and biochemistry of Olea europaea. Environ Exp Bot 65: 210-219.
Rinehart L. 2008. Ruminant Nutrition for Graziers. ATTRA 1-20.

Schiere JB, Ibrahim MNM. 1989. Feeding of urea ammonia-treated rice straw: A compilation of miscellaneous reports produced by the straw utilization project. Pudoc, Wageningen.

Singh GP, Oosting SJ. 1992. A model for describing the energy value of straws. Indian Dairyman XLIV, pp. 32-327.

Sciences F, Sarani B, 2012. Saponin: Role in animal system. Vet World 5 (4): 248-254

Suharti S, Astuti DA, Wina E, Toharmat T. 2011. Rumen microbial in the in vitro fermentation of different rations of forage and concentrate in the presence of whole lerak (Sapidus rerak) fruit extract. Asian-Aust. J Anim Sci 24: 1086-1091.

Treutter D. 2006. Significance of flavonoids in plant resistance: A review. Environ Chem Lett 4: 147-157.

Tjitrosoepomo G. 1993. Taksonomi Tumbuhan Spermatophyta. Gadjah Mada University Press. Yogyakarta [Indonesian]

Tronchet M, Balague' C, Kroj T, Jouanin L, Roby D. 2010. Cinnamyl alcohol dehydrogenases $\mathrm{C}$ and $\mathrm{D}$, key enzymes in lignin biosynthesis, play an essential role in disease resistance in Arabidopsis. Mol Plant Pathol 11: 83-92.

Vasta V, Jerònimo E, Brogna DMR, Dentinho MTP, Biondi L, SantosSilva J, Priolo A, Bessa RJB. 2010. The effect of grape seed extract or Cistus ladanifer L. on muscle volatile compounds of lambs fed dehydrated lucerne supplemented with oil. Food Chem 119: 13391345 .

Yanti Y, Yayoya M. 2017. Agricultural by-products as feed for ruminants in tropical area: nutritive value and mitigating methane emission. Rev Agric Sci 5: 65-76.

Waghorn GC, McNabb WC. 2003. Consequences of plant phenolic compounds for productivity and health of ruminants. Proc Nutr Soc 62: 382-392.

Wanapat M, Cherdthong A, Phesatcha K, Kang S. 2013. Dietary sources and their effects on animal production and environmental sustainability. Anim Nutr 1: 96-103.

War AR, Paulraj MG, Ahmad T, Buhroo AA, Hussain B, Ignacimuthu S, Sharma HC. 2012. Mechanisms of plant defense against insect herbivores. Plant Signaling Behav 7: 1306-1320.

Wina E, Sutanto H. 2016. Bab VIII. Senyawa bioaktif saponin sebagai agen defaunasi dan mitigasi gas metana pada ruminansia. In: Potensi Bahan Pakan Lokal, 170-188 [Indonesian]

Wina E. 2005. The impact of saponins or saponin-containing plant materials on ruminant production a review. J Agric Food Chem 53: 8093-8105. 